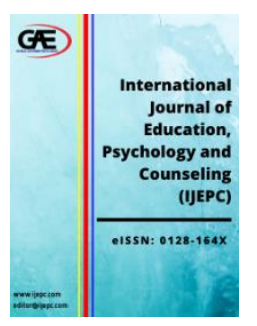

International Journal of Education, Psychology and Counselling (IJEPC)

Journal Website: http://ijepc.com/ eISSN: 0128-164X

\title{
THE ROLE OF SATISFACTION ON UNIVERSITY BRAND PERFORMANCE: A CASE STUDY AT HO CHI MINH CITY UNIVERSITY OF TECHNOLOGY
}

\author{
Le Thi Bich Diep
}

1 Department of Management and Business, HCMC University of Technology (HUTECH), Vietnam Email: ltb.diep@hutech.edu.vn

\section{Article Info:}

\section{Article history:}

Received date:04.02.2020

Revised date: 09.02 .2020

Accepted date: 11.02 .2020

Published date: 15.03.2020

To cite this document:

Diep, L. T. B. (2020). The Role of Satisfaction on University Brand Performance: A Case Study at Ho Chi Minh City University of Technology. International Journal of Education, Psychology and Counseling, 5 (34), 126-136.

DOI: $10.35631 /$ IJEPC.5340010.

\begin{abstract}
:
Students were the main customers of universities. As such, providing service quality of education and satisfying students' needs as well as expectations were vital for universities to succeed. This research focused on the relationship between education service quality (facilities, library, lecturers, administration staff, curriculum, extracurricular activities, and course management) and university brand performance through student's satisfaction. A questionnaire was distributed to 272 last-year students at Ho Chi Minh City University of Technology (HUTECH). The convenience sampling method was used. The reliability and validity of the instruments were fitted and showed high value. A path analysis was conducted to identify the impact of the relationship between concepts. The results of the research also indicated that student satisfaction played a mediator role in the impact of education service quality on university brand performance. The findings of this research would provide a recommendation for managers to determine the sustainability of the university by looking at the education service quality.
\end{abstract}

\section{Keywords:}

Service Quality; Student Satisfaction; University Brand Performance; Mediator Role

\section{Introduction}

Higher education has become popular in Vietnam. In 2015, the number of Vietnam universities was 219, but later went up to 237 universities in 2019 (Ministry of Education and Training Vietnam, 2019). This stemmed from the rapidly increasing demand for university 
education of Vietnamese people. Studying in university was evident in their minds, include contestants and their parents.

Thus, the increase in the supply and demand of such programs was contributing to the boosting in the education quality. To attracting contestants, the universities had to operate more effective, including improve the service quality and incorporated many media activities in order to promote the brand image (Panda et al., 2019). Meanwhile, when opting for the university, contestants have more options and would be learned in a better environment.

Although there were many factors that affected the choice of the university, but the university's brand remained one of the leading factors that were considered (Soni and Govender, 2018). Clearly, student could be seen as an effective communication channel for the university. Therefore, branding was the core problem for the University. It was not only a process of building long-term achievement and accumulations of students, parents, business social recognition, but it also was a separate identity to create the unique mark. Brand value was impacted of many factors, among which was the core element of service quality training that the university offered. However, in Vietnam, much of the research was done in order to measure student satisfaction in the quality of training services at the school, there was less attention to the brand. Heck et al. (2000) asserted that universities, to enhance value in service quality and university brand performance, they had to truly strive for continuous improvement and focused on stakeholders, especially learners. Therefore, consider the impact of quality training services to brand the University through student satisfaction was essential.

\section{Literature Review}

The terms service quality and service quality of education was difficult to define. It depended on the customers who were using the service. In a higher education environment, customers could be students, lecturers, employers, society, etc. In particular, students were the most obvious customers to use this service directly.

Service quality was a comparison of a consumer's general expectations with their actual perceptions of a firm (Parasuraman et al., 1993). Athiyaman (1997) argued that service quality was an overall evaluation of the goodness or badness of product or service.

Education service was a process that provided the knowledge to students/learners. The learner was the most important component, strong interaction with each other and decide the quality of the process. In addition, the activities of the functional units and other units, such as departments, the academic, library, laboratories, and other school services also contributed to the process of conveying knowledge was smoothly convenient and easier (Sultan and Wong, 2014).

The service quality in higher education was considered the level of measurement of the response of universities to the needs (at present, implicit) of students (Sultan and Wong, $2018 \&$ 2014). It was viewed as the ability to meet learning needs as well as the service of the school for students. It was the difference between student's expect about the university and actual receive (Voss et al, 2007).

Evaluate the quality of training services was the issue receiving great attention from researchers in and outside the country, as well as the managers of education. 
Gronroos (1984) argued that two types of service quality: (1) Technical quality and (2) Functional quality.

Technical quality related to what was provided during the service process. It was knowledge, tangibles and technical solutions.

Functional quality referred to how the service was provided, and the interpersonal behaviours contributed by the service employee during the service encounter.

The most widely model used for measuring service quality was the SERVQUAL model, developed by Parasuraman et al. (1993). It included five dimensions: (1) Tangibles, (2) Reliability, (3) Responsiveness, (4) Assurance, (5) Empathy.

Tangibles related to physical facilities, equipment, personnel and communication materials.

Reliability was the ability to perform the promised service dependably and accurately. Responsiveness was the willingness to help customers and to provide prompt service.

Assurance was the knowledge and courtesy of employees and their ability to convey trust and confidence.

Empathy related to caring, individualised attention the firm provides its customers.

Siskos et al. (2005) asserted that education services should consider in three aspects: (1) Education, (2) Facilities, (3) Administrative support.

Education related to curriculum, extracurricular activities and the competence of lecturers.

Facilities were mentioned as the room, the physical conditions-equipment, library serves for learning, student activities, and student research.

Administrative included administrative activities related to the course management and administration staff.

Panda et al. (2019) stated that service quality of education was evaluated by various dimensions such as academics, teaching, research, administration and staff, sports and extracurricular activities, the general environment and the various facilities.

Many researchers agreed that the students experience on the education service during the time period under study would be the basis for their reviews of the level of general satisfaction about the university. The relationship between these concepts were concerned, the conclusion by many research results of different experiments, such as the research results of Panda et al. (2019), Sultan and Wong (2018 \& 2014), Khoo et al. (2017), Zakaria et al. (2016), Siming et al. (2015), Hasan and Masri (2013), Seng and Ling (2013), etc. So, if the service quality in the university was higher, their students were more satisfied.

Student satisfaction was defined as the perceived value of the quality education service of student (Chiu, 2002). With point of view, Chiu said that this was the reviews of services Copyright (C) GLOBAL ACADEMIC EXCELLENCE (M) SDN BHD - All rights reserved 
offered by the university, about the results of the activities related to education. As Moore (2005) argued that, the students have been satisfied when the students succeeded in the learning process and felt content with the learning process. It meant that students were enjoying with the completion of the learning environment. This definition focused on the achievements and success in learning and consent as well as known to enjoy his experience. $\mathrm{Wu}$ et al. (2010) defined to the satisfaction of the students as the synthesis of attitude and feeling of students on study results which were aggregated from all the benefits that a student hoped to get with real results that they got from the learning environment. It reflected the results of the mutual exchange between lecturers and students, between students and the university (Thurmond et al., 2002). In particular, this satisfaction related to three aspects: (1) Overall, (2) Compared with the expected and (3) Compared to an ideal situation (Thomas and Galambos, 2004; Ryan et al., 1995).

Panda et al. (2019) and Edvardsson et al. (2000) said that customer satisfaction did not only affect the loyalty of customers, but also the image, reputation, brand of the company. For the universities, enhance the value of brand image, reputation, attracting students in attendance was the result that the university achieved when focusing on improving students' overall satisfaction (Sultand and Wong, 2018). Because this satisfaction would strongly impact to the brand performance that the university were building (Sultan and Wong, 2018 \& 2014; Helgesen and Nesset, 2007; Mavondo et al., 2000; ...).

Chapleo (2010) said that, when mentioning the name of a University, then immediately evoked the "imagination, emotions, images" about the university of students. And the task of building the University brand was built, managed and developed its impression. Meanwhile, Lewis (2011) said that, in the context of higher education, a brand could be described as a name, a picture, and a fascinating description of a field have the ability to capture the essence of the value that the University offers. In this research, the brand was the impression or perception of the image, the identity field for the parties concerned, with regard to outside organizations. The construction of university brand was viewed as essential to attracting and retaining students. Building a good brand's image, service quality was the key factor. Associate professor Heck et al. (2000) said that the University had to create the service quality and useful research activities, acknowledged by students, social and business community. This was always a factor in the study compared with universities when choosing the University brand. Helgesen and Nesset (2007) pointed out that improving the quality education services in university not only brought to overall satisfaction for the students, but also the elements that made up the brand performance of the University (Sultan and Wong, 2018).

From previous researches, this paper showed that three main factors including education, facilities and administrative measured service quality in higher education. These factors interacted and supported each other. The result of this service quality was graduate, learning outcomes, satisfaction or dissatisfaction, etc. which led to student's loyal, university image, reputation, university brand performance. Figure 1 showed these relationships. 


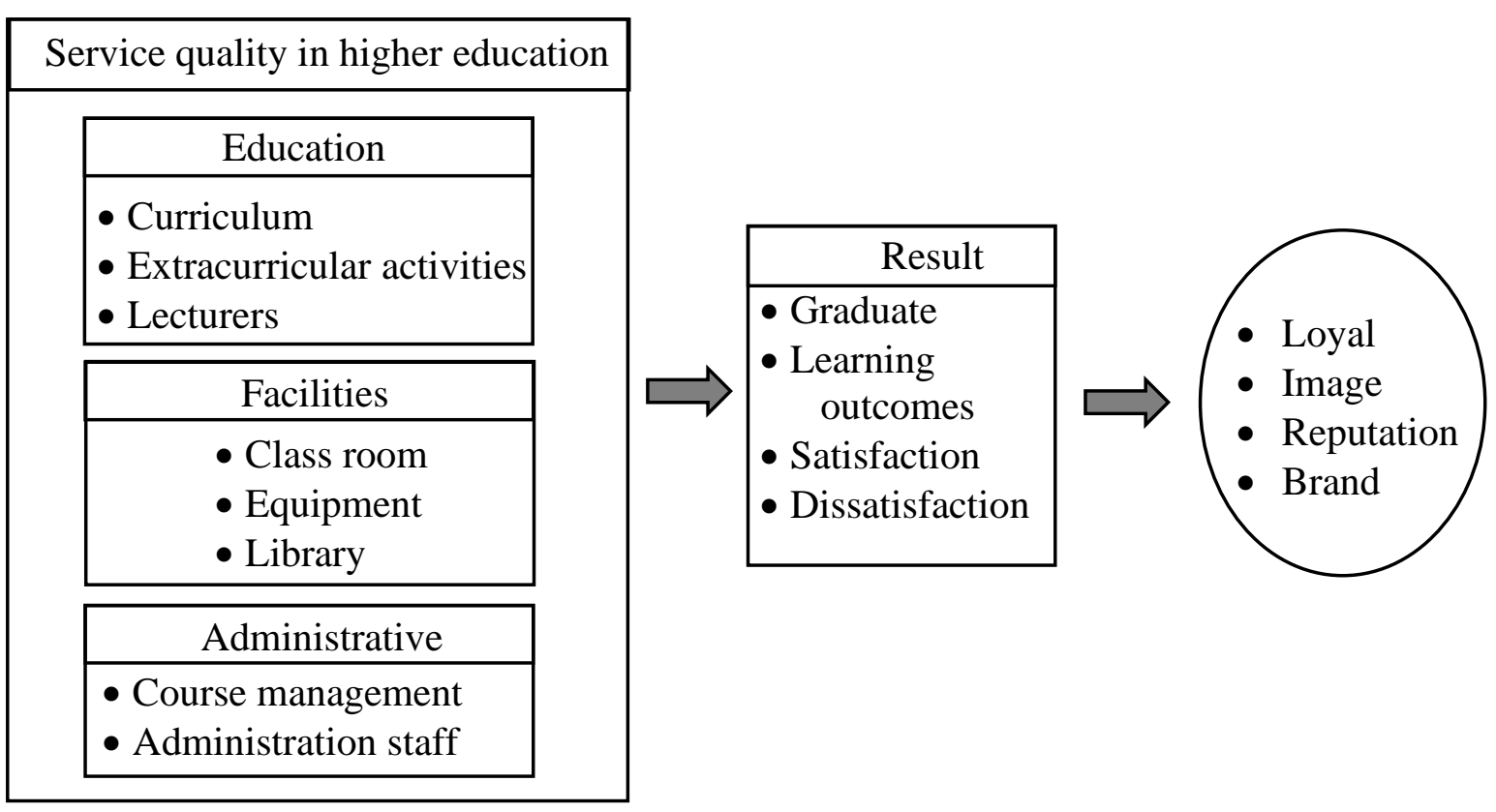

Figure 1. Theoretical Framework

In summary, the main concepts of research were testing the relationship between the elements of the service quality education and university brand performance, through the mediator role of the student satisfaction. Thus, hypothesizes were proposed that:

$\mathrm{H}_{1}$ : Facilities has a positive impact on student satisfaction

$\mathrm{H}_{2}$ : Library has a positive impact on student satisfaction.

$\mathrm{H}_{3}$ : Lecturers has a positive impact on student satisfaction.

$\mathrm{H}_{4}$ : Curriculum has a positive impact on student satisfaction.

$\mathrm{H}_{5}$ : Extracurricular activities have a positive impact on student satisfaction.

$\mathrm{H}_{6}$ : Administrative Staff have a positive impact on student satisfaction.

$\mathrm{H}_{7}$ : Course management has a positive impact on student satisfaction.

$\mathrm{H}_{8}$ : Student satisfaction has a positive impact on university brand performance.

\section{Methodology}

To achieve the object of this research, nine scales were constructed based on previous research (Sultan and Wong, 2018\& 2014; Saif, 2014; Ibrahim et al., 2014; Farahmandian et al., 2013; Letcher and Neves, 2010; Bell, 1994). In particular: Facilities, library, lecturers, curriculum, extracurricular activities, administrative staff, course management, student satisfaction and university brand performance. All items were developed in English but were revised and modified in Vietnam depending on this research objective and characteristics of the subjects.

A questionnaire consisting of 50 questions was used. All items were measured on a Likert five - point scale, from "strongly disagree" to "strongly agree". 
The questionnaires were sent to last - year students of Ho Chi Minh City University of Technology who were enough experience to assess the service quality in their university. Data was collected by a convenient sampling method. Total of 400 questionnaires were issued and 272 valid samples. The scales were evaluated by the reliability scale, and exploratory factor analysis (EFA). To test the model, this research used the PATH model. The software SPSS 20.0 was used in analyses the data.

\section{Results}

Table 1 reported the results of reliability analysis for the facilities, library, lecturers, curriculum, extracurricular activities, administrative staff, course management, student satisfaction and university brand performance. The reliability test was performed on all the items that were presumed to measure the scales. The Cronbach's Alpha for all scale exceeded threshold value of 0.7 . However, one observation of facilities was eliminated. The results of EFA found that eight observations were eliminated.

Table 1. Result of Reliability

\begin{tabular}{|l|c|c|}
\hline \multicolumn{1}{|c|}{ Scale } & Number of Items & Cronbach's Alpha \\
\hline Facilities & 7 & 0.742 \\
\hline Library & 6 & 0.890 \\
\hline Lecturers & 7 & 0.889 \\
\hline Curriculum & 4 & 0.806 \\
\hline Extracurricular activities & 5 & 0.905 \\
\hline Administrative Staff & 6 & 0.902 \\
\hline Course management & 6 & 0.874 \\
\hline Student satisfaction & 4 & 0.792 \\
\hline University brand performance & 4 & 0.849 \\
\hline
\end{tabular}

The results of regression analysis indicated that the model 1 and model 2 were fit, exhibited positive and statistically significant relationship in $\mathrm{F}$ statistics. The $\mathrm{R}^{2}{ }_{1}$ adjusted indicated that seven dimensions explained $49.4 \%$ of variance in determining student satisfaction. Meanwhile, $45.7 \%$ of the variation on university brand performance was explained by the student satisfaction $\left(\mathrm{R}^{2}{ }_{2}=0.457\right)$.

$\mathrm{R}^{2}{ }_{\mathrm{M}}=1-\left(1-\mathrm{R}_{1}{ }_{1}\right) *\left(1-\mathrm{R}^{2}{ }_{2}\right)=1-(1-0.494) *(1-0.457)=0.725=72.5 \%$

So, the coefficient of synthetic suit of this model was $72.5 \%$.

Table 2. Coefficients

\begin{tabular}{|c|c|c|c|c|c|c|c|c|}
\hline \multirow{2}{*}{\multicolumn{2}{|c|}{ Model }} & \multirow[t]{2}{*}{ B } & \multirow{2}{*}{$\begin{array}{l}\text { Std. } \\
\text { Error }\end{array}$} & \multirow[t]{2}{*}{ Beta } & \multirow[t]{2}{*}{$\mathbf{t}$} & \multirow[t]{2}{*}{ Sig. } & \multicolumn{2}{|c|}{$\begin{array}{l}\text { Collinearity } \\
\text { Statistics }\end{array}$} \\
\hline & & & & & & & Tolerance & VIF \\
\hline \multirow{6}{*}{1} & (Constant) & 0.243 & 0.185 & & 1.317 & 0.189 & & \\
\hline & Facilities & 0.114 & 0.050 & 0.111 & 2.277 & 0.024 & 0.791 & 1.265 \\
\hline & Library & 0.108 & 0.054 & 0.117 & 2.012 & 0.045 & 0.556 & 1.800 \\
\hline & Lecturers & 0.161 & 0.056 & 0.161 & 2.850 & 0.005 & 0.588 & 1.700 \\
\hline & Curriculum & 0.114 & 0.051 & 0.129 & 2.222 & 0.027 & 0.551 & 1.814 \\
\hline & $\begin{array}{l}\text { Extracurricular } \\
\text { activities }\end{array}$ & 0.112 & 0.053 & 0.128 & 2.115 & 0.035 & 0.508 & 1.970 \\
\hline
\end{tabular}




\begin{tabular}{|c|c|c|c|c|c|c|c|c|}
\hline & Administrative Staff & 0.210 & 0.056 & 0.221 & 3.728 & 0.000 & 0.531 & 1.883 \\
\hline & Course management & 0.103 & 0.050 & 0.118 & 2.039 & 0.042 & 0.558 & 1.793 \\
\hline & $\mathrm{R}^{2}{ }_{1}$ adjusted & \multicolumn{7}{|l|}{0.494} \\
\hline & Durbin - Watson & \multicolumn{7}{|l|}{2.016} \\
\hline & $\mathrm{F}$ & \multicolumn{7}{|c|}{38.746} \\
\hline & Sig. & \multicolumn{7}{|c|}{0.000} \\
\hline & \multicolumn{8}{|c|}{ Dependent $_{\mathrm{a}}$ : Student Satisfaction } \\
\hline \multirow{7}{*}{2} & (Constant) & 0.769 & 0.157 & & 4.910 & 0.000 & & \\
\hline & Satisfaction & 0.744 & 0.049 & 0.676 & 15.070 & 0.000 & & \\
\hline & $\mathrm{R}_{2}^{2}$ & \multicolumn{7}{|l|}{0.457} \\
\hline & Durbin - Watson & \multicolumn{7}{|c|}{1.915} \\
\hline & $\mathrm{F}$ & \multicolumn{7}{|c|}{227.106} \\
\hline & Sig. & \multicolumn{7}{|c|}{0.000} \\
\hline & \multicolumn{8}{|c|}{ Dependent $t_{\mathrm{b}}$ : University Brand Performance } \\
\hline
\end{tabular}

The results of the regression analysis showed the impact of the seven factors to the student satisfaction. All factors which showed statistical significance to student satisfaction were facilities $(\mathrm{t}=2.277, \rho=0.024)$, library $(\mathrm{t}=2.012, \rho=0.045)$, lecturers $(\mathrm{t}=2.850, \rho=0.005)$, curriculum ( $\mathrm{t}=2.222, \rho=0.027)$, extracurricular activities $(\mathrm{t}=2.115, \rho=0.035)$, administrative staff $(t=3.728, \rho=0.000)$, course management $(t=2.039, \rho=0.042)$. The impact of this satisfaction to the university brand performance had significance $(t=15.070, \rho=0.000)$.

Table 3 showed a summary of results for hypothesizes in the research model. The significance of the estimates was identified. Besides, student satisfaction was full mediation in the relationship between service quality and university brand performance.

The result showed, the administrative staff had the most strongly influenced to student satisfaction $($ Beta $=0.221)$, next to lecturers $($ Beta $=0.161)$, curriculum $($ Beta $=0.129)$, extracurricular activities $($ Beta $=0.128)$, course management $($ Beta $=0.118)$, library $($ Beta $=$ 0.117). The facilities were the lowest impact factors to the satisfaction of the students (Beta $=$ 0.111). Satisfaction was also affecting the University brand performance with Beta $=0.676$ (Table 2).

\section{Table 3. Result of research Hypothesis}

\begin{tabular}{|l|c|}
\hline \multicolumn{1}{|c|}{ Hypothesizes path } & Decision \\
\hline $\mathrm{H}_{1}:$ Facilities has a positive impact on student satisfaction & Supported \\
\hline $\mathrm{H}_{2}:$ Library has a positive impact on student satisfaction & Supported \\
\hline $\mathrm{H}_{3}:$ Lecturers has a positive impact on student satisfaction & Supported \\
\hline $\mathrm{H}_{4}:$ Curriculum has a positive impact on student satisfaction & Supported \\
\hline $\mathrm{H}_{5}:$ Extracurricular activities have a positive impact on student satisfaction & Supported \\
\hline $\mathrm{H}_{6}:$ Administrative Staff have a positive impact on student satisfaction & Supported \\
\hline $\mathrm{H}_{7}:$ Course management has a positive impact on student satisfaction & Supported \\
\hline $\mathrm{H}_{8}:$ Student satisfaction has a positive impact on university brand performance & Supported \\
\hline
\end{tabular}

The finding showed that, when the universities enhanced the services quality education as facilities, library, lecturers, curriculum, extracurricular activities, administrative staff, course 
management, the students would be more satisfied, and value of the brand was enhanced. Therefore, to enhance the brand value of universities, the managers not only captured to direct impact factors such as student satisfaction, which needed attention to the factors that impacted indirectly through the satisfaction as administrative staff, lecturers, curriculum, extracurricular activities, course management, facilities.

The administrative staff were the most influential factor of the University brand performance through intermediate variables which were the satisfaction of the students. The administrative staff were human factors which indirectly made the education process of the university to be evaluated through several aspects: respect for the students, the attitude in solving questions of students, the ability to respond quickly, helpful, polite outfit, etc. So, the university wanted to enhance the satisfaction of students, as well as enhancing the brand value, they needed to improve the work style and attitude of the staff.

The lecturers were the second most influential factors to the university brand performance through intermediate variables which were student satisfaction. The university needed to improve quality of the teaching. The lecturers directly performed teaching and could affect the process of teaching, as well as having a direct influence on the quality education services. The teachers not only were reviews in a professional capacity, but also in pedagogical methods, implementation of the plan of teaching, enthusiasm, evaluation of learning results precisely, share practical experience, closely with students.

The design of the curriculum related to the construction of the structure, content and outputs of a program. In contrast, the outputs associated closely with the courses in the training program. The outputs were the cornerstone of service quality by towards the benefit of learners. The curriculum had a very important significance and was seen as a strategy, if a good curriculum would attract more students into the university. A bad curriculum would cause boredom for students, which could lead to dissatisfaction of the students and reduce the university brand performance.

Extracurricular activities related to all cultural activities, sports, and the society outside of the classroom. This was one of the playing fields for the students who were volunteers in participation according to the needs, the possibility. For extracurricular activities, students played a huge role not only in the process of learning involved in university but also after graduate. Therefore, diverse extracurricular activities were cultural activities, academic competitions, career activities, the science of soft skills and community living programs.

The managers of the university were next factor to impact the University brand performance through intermediate variables. Each university should have developed policy and strategy in the medium term and the long term in building management, lecturers, staff; strengthening the management of educational personnel; building and perfecting the organization, units in strong, professional to meet student learning needs.

Although the library was the influence of a very small element to the student satisfaction and the University brand performance, but it should be considered. The library of the university met the satisfaction of students. There were many documents for reference, fairly comfortable space, electronic library for easy retrieval of documents, opening and closing periods match, 
etc. Borrow and return the book's procedure was easy. Book's borrow time should be longer because students had to study, participate in extracurricular activities, work part time, etc.

The facilities of the university including class equipment, class furniture, wifi network all met the learning needs of students. However, the university regularly maintain as well as enhance the equipment for classrooms. Besides, a fitting set number of students in each grade was the best way to give students the finest learning space.

\section{Conclusion}

The objective of this research was to examine the influence of facilities, library, lecturers, curriculum, extracurricular activities, administrative staff, and course management with the university brand performance through satisfaction of students. Research results also showed the satisfaction of students play the role of mediators between service quality and the university brand performance. The results of this research again confirmed the results of research of Sultan and Wong. (2018 \& 2014), Farahmandian et al. (2013), Seng and Ling (2013), Topala et al. (2013), Suarman et al. (2013). Research had the overall look and the more comprehensive satisfaction of students through quality education service of the university.

Thereby, this research provided several valuable implications for managers in developing university. If the university wanted to engage the contestants in increasing choice and maintain the number of students in course, the managers needed to understand the implication of the influencing factors. The managers should seek ways to improve service quality in the university in day by day. Administrative staff should have a positive attitude and support students enthusiastically. The managers needed to promote lecturers in improving teaching capacity and teaching methods to best convey knowledge and support students. The curriculum should to update usually in accordance with the needs of society. The extracurricular activities should be built based on the needs of students and for students to actively participate and manage these activities.

Also, the student experiences needed to be monitored and used as information to improve services. So, the managers should focus on building measure process for service quality. It ensured clearly, specifically and stability. The measurement results needed to use to improving service quality in the university. Moreover, the managers needed to make the clearest statement about using this measurement results and announce it publicly to students to participate actively in assessing the quality of service of the university.

The research was subject to certain limitations. The theoretical framework of this study was tested in a university, so it did not have the representational. The framework should be tested in other markets because there might be differences. On the other hand, the convenience sampling method was selected. Consequently, it was not feasible to generalize the results obtained from this research. This research examined only some of the major factors. It could skip some social factors that affected students as family, learning conditions, or psychological factors such as students' preferences, expectations, etc. Future research could examine the impact of these factors. 


\section{Reference}

Athiyaman, A. (1997). Linking student satisfaction and service quality perceptions: the case of university education. European journal of marketing.

Bell, S. (1994). Student Satisfaction at York University, Canada.

Chapleo, Chris, 2010. "What defines "successful" university brands?" International Journal of Public Sector Management 23.2: 169-183.

Chiu, Kuan-Yao Charles, 2002. Relationships among student demographic characteristics, student academic achievement, student satisfaction, and online business-course quality. USA: Ann Arbor, p.103.

Edvardsson, B., Johnson, M. D., Gustafsson, A., \& Strandvik, T, 2000. The effects of satisfaction and loyalty on profits and growth: products versus services. Total quality management, 11(7), 917-927.

Farahmandian, S., Minavand, H., \& Afshardost, M. (2013). Perceived service quality and student satisfaction in higher education. Journal of Business and Management, 12(4), $65-74$.

Gronroos, C. (1984). A service quality model and its marketing implications.

Hasan, Lujain Mohammed, \& bin Masri, Ridzuan, 2013. Factors Influence the Satisfaction of International Students at Private Universities in Malaysia. International Journal of Science and Research, 6(14).

Heck, R. H., Johnsrud, L. K., \& Rosser, V. J. (2000). Administrative effectiveness in higher education: Improving assessment procedures. Research in higher education, 41(6), 663-684.

Heck, Ronald H, Johnsrud, Linda K, \& Rosser, Vicki J, 2000. Administrative effectiveness in higher education: Improving assessment procedures. Research in higher education, 41(6), 663-684.

Helgesen, Ø., \& Nesset, E. (2007). Images, satisfaction and antecedents: Drivers of student loyalty? A case study of a Norwegian university college. Corporate Reputation Review, 10(1), 38-59.

http://dantri.com.vn/giao-duc-khuyen-hoc/xay-dung-thuong-hieu-cho-mot-truong-dai-hocphai-bat-dau-tu-dau-20170311161442526.htm

Ibrahim, Mohd Zuhdi, Ab Rahman, Mohd Nizam, \& Yasin, Ruhizan M, 2014. Determining Factors of Students' Satisfaction with Malaysian Skills Training Institutes. International Education Studies, 7(6), 9-24.

Khoo, S., Ha, H., \& McGregor, S. L. (2017). Service quality and student/customer satisfaction in the private tertiary education sector in Singapore. International Journal of Educational Management.

Letcher, D. W., \& Neves, J. S. (2010). Determinants of undergraduate business student satisfaction. Research in Higher Education Journal, 6, 1.

LEWIS, Tyson E, 2011. The future of the image in critical pedagogy. Studies in Philosophy and Education, 30.1: 37-51.

Mavondo, Felix, Zaman, Manir, \& Abubakar, Binta, 2000. Student satisfaction with tertiary institution and recommending it to prospective students. Paper presented at the Australia, New Zealand Management Academy Conference.

Moore, Janet C, 2005. The Sloan Consortium quality framework and the five pillars. The Sloan Consortium. Retrieved July, 15, 2007.

Panda, S., Pandey, S. C., Bennett, A., \& Tian, X. (2019). University brand image as competitive advantage: a two-country study. International Journal of Educational Management. 
Parasuraman, A., Berry, L. L., \& Zeithaml, V. A. (1993). More on improving service quality measurement. Journal of retailing, 69(1), 140-147.

Ryan, Chris, 1995. Researching tourist satisfaction: issues, concepts, problems. London and New York: Routledge

Saif, N. I. (2014). The effect of service quality on student satisfaction: a field study for health services administration students. International Journal of Humanities and Social Science, 4(8), 172-181.

Seng, Ernest Lim Kok, \& Ling, Tan Pei, 2013. A statistical analysis of education service quality dimensions on business school students' satisfaction. International Education Studies, 6(8), 136.

Siming, Luo, Gao, Jianying, Xu, Dan, \& Shaf, Khurrum, 2015. Factors Leading to Students' Satisfaction in the Higher Learning Institutions. Journal of Education and Practice, 6(31), 114-118.

Siskos, Y, Bouranta, N, \& Tsotsolas, N, 2005. Measuring service quality for students in higher education: the case of a business university. Foundations of Computing and Decision Sciences, 30(2), 163-180.

Soni, S., \& Govender, K. (2018). The Relationship between Service Quality Dimensions and Brand Equity: Higher Education Students' Perceptions. Journal of Management and Business Administration. Central Europe, 26(3), 71-87.

Sultan, P., \& Wong, H. Y. (2018). How service quality affects university brand performance, university brand image and behavioural intention: The mediating effects of satisfaction and trust and moderating roles of gender and study mode. Journal of Brand Management, 26(3), 332-347.

Sultan, Parves, and Ho Yin Wong, 2014. An integrated-process model of service quality, institutional brand and behavioural intentions. Managing Service Quality, Vol. 24 Iss 5 pp. 487 - 521.

Thomas, Emily H, \& Galambos, Nora, 2004. What satisfies students? Mining student-opinion data with regression and decision tree analysis. Research in Higher Education, 45(3), 251-269.

Thurmond, Veronica A, Wambach, Karen, Connors, Helen R, \& Frey, Bruce B, 2002. Evaluation of student satisfaction: Determining the impact of a web-based environment by controlling for student characteristics. The American journal of distance education, 16(3), 169-190.

Voss, R., Gruber, T., \& Szmigin, I. (2007). Service quality in higher education: The role of student expectations. Journal of Business Research, 60(9), 949-959.

$\mathrm{Wu}$, Jen-Her, Tennyson, Robert D, \& Hsia, Tzyh-Lih, 2010. A study of student satisfaction in a blended e-learning system environment. Computers \& Education, 55(1), 155-164.

Zakaria, Nurulhaida, Umar, Rozila, Deraman, Wan Husna Aini Wan, \& Mutalib, Sharifah Sakinah Syed Abd, 2016. Regression Analysis on Factors Influencing Students' Satisfaction towards Program Courses. Indian Journal of Science and Technology, 9(17). 